\title{
Evaluation of Slovakia's R1 expressway enhancement impacts on local socio-economic development: expert panel approach
}

\author{
RICHARD FILČÁK ${ }^{1}$, ALENA ROCHOVSKÁ ${ }^{2}$, MARCEL HORŇÁK ${ }^{2}$
}

1 Centre of Social and Psychological Sciences, Slovak Academy of Sciences, Bratislava, Slovakia; e-mail: progrfil@savba.sk

2 Comenius University in Bratislava, Faculty of Natural Sciences, Department of Economic and Social Geography, Demography and Territorial Development, Bratislava, Slovakia; e-mail: alena.rochovska@uniba.sk, marcel.hornak@uniba.sk

ABSTRACT Transport infrastructure development is considered one of the basic structural preconditions of competitiveness, growth and economic development in Slovakia. Transport network upgrading in the country has recently been focused mainly on road and motorway networks. The goal of this paper is to contribute to existing approaches to transport infrastructure impact assessment. The paper presents selected results of qualitative research focused on an analysis of the R1 expressway (as a part of TEN-T network) and its impacts on the economic, social and environmental dimensions of life at the local territorial level. The paper also seeks to answer the basic question, whether and to what extent the new section of the expressway brings any stimuli to regional or local development. Qualitative research realized by field sociological methods has shown new data and information necessary for a complex assessment of transport infrastructure impacts on social and economic development of regions. We assume that these impacts should not be based purely on mathematic and statistical research methods.

KEY WORDS transport - R1 expressway - Slovakia - investment - direct and indirect impacts

FILČÁK, R., ROCHOVSKÁ, A., HORŇÁK, M. (2021): Evaluation of Slovakia's R1 expressway enhancement impacts on local socio-economic development: expert panel approach. Geografie, 126, 1, 29-53.

https://doi.org/10.37040/geografie2021126010029

Received August 2020, accepted January 2021.

CC Česká geografická společnost, z. s., 2021 


\section{Introduction}

Transport related social and economic development seems to be a very complex matrix of relationships and impacts, only partly detectable by quantitative analyses. Even if sophisticated approaches are applied, the results are often vague and ambiguous, partly as a consequence of unavailable data and unclear weight of particular factors (Mičúch, Tvrz 2015; Mikloš, Habrman 2018). There are often many controversies which may lead to misinterpretations. No detectable decline of traffic accident frequencies on a new motorway section can be a result of considerably rising traffic volumes after opening the motorway (Vickerman 2000; Viturka, Pařil, Tonev 2012). A decline of unemployment rates in regions located along a new motorway section might be a consequence of improved accessibility times and outmigration of labour force from peripheral communities rather than a result of a concentration of new investments into local economy alongside the motorway (for more details see for instance Vickerman, Spiekermann, Wegener 1999, Viturka, Pařil 2015). On the other hand, we must admit that outcomes of a qualitative research focused on quality-of-life improvements, reduced travel time or benefits for local authorities can also show only a part of the reality. Therefore, the transport network investments should be evaluated in their complexity revealing both positive as well as negative externalities of such investments.

The aim of the paper is to map and evaluate both direct and indirect social, environmental as well as economic impacts of a new motorway network section and contribute to a more complex insight into the issue of new motorway network effects. As a reflection to existing quantitative research studies (see Habrman, Žúdel 2017 or Mikloš, Habrman 2018) our intention is to focus on a qualitative approach to socio-economic impacts of the motorway network extension in west Slovakia after 2000 (see Fig. 1 below).

Qualitative survey methods are being used increasingly in research and policy studies to understand traveler perceptions, attitudes and behavior, as a complement to more established quantitative surveys of public perceptions, attitudes and behavior. The qualitative research on which our paper is based was focused on a belt of territory along the R1 expressway stretching between Trnava and Banská Bystrica (two regional centres in western and central Slovakia). Most parts of this territory show relatively well developed economies compared to regions in their hinterland, disconnected from the TEN-T motorway network. We should also emphasize that the whole area in focus has been repeatedly reported as a relatively successful in terms of recent economic and social development indicators (Korec et al. 2005, Michniak 2015) due to its proximity to major Central-European metropolises such as Bratislava (the national capital), Vienna or Budapest. Although the impact of the new transport infrastructure is often manifested in the regions 
through which it does not pass directly, our analyses were focused on the area directly affected by the construction.

Slovakia with its $18,057 \mathrm{~km}$ of national and regional roads (as of 2017) is one of the European countries with a lower density of the road network (Hamada, Kasagranda 2012; Mikloš 2016; SSC 2018). Support of sustainable mobility via transport infrastructure upgrading has been one of the key priorities of the European Structural and Investment Funds (ESIF) and was the core aim of the Operational Programme Transport which was Slovakia's principal programming document supporting implementation of transport sector projects financed by the European Union within 2007-2013 period (MDVRR SR 2015). The Operational Program Integrated Infrastructure, in the subsequent programming period 20142020, has development of passenger transport among the priorities as well. The investments are supposed to improve regional accessibility within the country, which (in synergy with realization of other Operation Programmes) should support overal goals of decreasing regional disparities, support of economic activities development and growing competitiveness of Slovakia.

Investments into roads should further improve density of core road network, remove bottlenecks, enhance safety of the transport and improve intra- and interregional accessibility. Road traffic safety and decreasing accident frequency are other specific indicators listed as benefits of road network upgrading.

The question arising is to what extent are these goals and objectives fulfilled. Analyses of new motorway infrastructure impacts recently published in Slovakia usually cover changing number and structure of relevant businesses, incomes of local authorities and local labour market turbulence (such as Hamada, Kasagranda 2012; Mičúch, Tvrz 2015; Mikloš 2016). The authors often conclude that a quantification of the impacts is sometimes disputable and macroeconomic effects of new motorways can only be predicted with a questionable accuracy. Apart from the motorway infrastructure, economic growth, labour market development and secondarily also incomes of regional and local authorities depend on a wide mix of attributes, structural conditions, barriers and incentives, human capital, local/ regional business environment, accessibility of resources, institutional conditions, policies of central, regional and local authorities, accessibility of markets, attractiveness of environment, life-quality and many others (more discussions can be found in e.g. Krugman 1991; Bruinsma, Rienstra, Rietveld 1997; Banister, Berechman 2001; Korec et al. 2005, Viturka, Pařil 2015; Chvátal 2018 and many others). Although theoretical expectations include positive redistributional effects on regions or municipalities, possible negative effects can be sometimes detectable only by a profound qualitative survey (Chvátal 2018).

Some of the recent quantitative analyses on motorway network development in Slovakia and its economic effects (Mikloš 2016; Habrman, Žúdel 2017; Mikloš, Habrman 2018; Baláž, Dokupilová, Nežinský 2018) resonate with theoretical 
expectations and indicate that terminal metropolitan regions and/or closeby regions can profit most from the new infrastructure. Komornicki et al. (2013) also reports on improvement of cohesion with internal peripheral areas induced by large-scale transport network improvements, as predicted by some political documents. On the other hand, transit regions may face a slight outflow of economic activities shifting to core regions. Anyway, the above-mentioned recent studies confirm diversified social, economic and environmental effects on transit and metropolitan regions as demonstrated by studies published abroad. A complementary qualitative survey might extend existing statistical and quantitative analyses of direct and indirect effects of new motorway network sections and offer opportunities for future large-scale transport investment projects.

This paper aims to analyse effects of a new section of R1 expressway in Slovakia (expressways are an integral part of motorway network developed in the Slovak Republic). Given the completion of the considerable part of R1 expressway in 2011 it provides enough time for impacts evaluation and assessment of the local economic, social, and environmental trends using a qualitative approach. The qualitative methods were used here to reveal local perceptions of what stimuli were brought by the new infrastructure.

\section{Theoretical background}

\subsection{Transport and socioeconomic development: theoretical introduction}

Undoubtedly, transport systems and socio-economic development are closely related with each other. In the perspective of Oyesiku (2004), the approaches to transport provision as well as the efficiency of the transport system are directly related to the nature and dynamism of the transport policy of a country. Adler (1987) calls transport infrastructure a prerequisite, and somehow a guarantee of economic development. Economic opportunities emerge intensively in places or regions with developed transport networks enabling to meet the highest mobility demands and reach trade markets and natural resources (Rodrigue, Comtois, Slack 2009). Quality of such relationship may differ depending on territorial level (see more in Lakshmanan 2011; Guangqing 2014; Viturka, Pařil 2015). We agree with MacKinnon, Pirie, Gather (2009) who emphasize that transport systems (both networks and services) have better conditions for development in prosperous regions or societies. Conventional explanations of transport-economy links were based on interpretation of a mutual (two-way) relationship (well-developed transport supports growth of economy and vice versa, highly developed economy calls for more investments into transport systems). Recent scholarly books (such as Hoyle, Smith 1998 or Rodrigue, Comtois, Slack 2009) and numerous case studies 
(e.g. Banister, Berechman 2001; Viturka, Pařil, Tonev 2012; Kvizda 2017 and many others) indicate that in real environment these two phenomena are associated through highly complex and multidimensional links.

Apart from the well-known location theories rooted in classical economics, we focus attention to "new economic geography" introduced by Krugman (1991) who explains agglomeration advantages via low transportation costs. Krugman's new economic theory supports so-called polarization theories (see e.g. Perroux 1950 or Grzeszczak 1972) and indicates that better and more efficient transportation can generate further concentration of human activities in well-developed regions due to reduced transportation costs.

Impacts of transport organisation changes and transport network upgrading on social and economic development have been subject to extensive research, and most of such studies emphasize the need for multidisciplinary approaches. Rodrigue, Comtois, Slack (2009) state that generally, there are direct and indirect impacts on economics. The former ones refer to general change (mostly improvement) of accessibility which enables better access to larger markets and saves travel time and costs. The latter ones lie in a multiplier effect caused by transport improvements leading to lower costs of goods or services and their growing variability.

The relationship between transport and social and economic development is not unambiguous. Transport infrastructure investments are generally expected to bring positive impacts on economic growth at both regional and micro-regional dimensions (Holl 2004, Hensher et al. 2012, in Slovak literature see e.g. Korec 1983, Korec et al. 2005). Recent decades brought more commonsensible expert views on what transport infrastructure upgrading might really lead to. Numerous studies have shown that the effect of transport network investment does not guarantee a regional growth (Button 1995; Bruinsma, Rienstra, Rietveld 1997; Vickerman, Spiekermann, Wegener 1999; Viturka, Pařil, Tonev 2012). Recent role of transport networks in developed post-industrial countries having experienced various evolution stages seems to be somewhat different from transport infrastructure's mission in underdeveloped countries (see e.g. Banister, Berechman 2001). Studies focused on transport network modernisation effects show that spectrum of direct impacts of transport investments in rich countries is rather narrow compared to previous phases of their development trajectories (Vickerman, Spiekermann, Wegener 1999; Pšenka 2008; Marada, Květoň, Vondráčková 2006 a 2010; Hudeček, Churaň, Kufner 2011; Chmelík, Marada 2014; Michniak 2015; Borowska-Stefańska, Kowalski, Wiśniewski 2020 etc.).

The above arguments do not anyhow question the role of transport infrastructure in sustainable economic growth. Reliability of transport networks and services remains the key attribute of transport network in developed countries. As many indicate (e.g. Banister, Berechman 2001; MacKinnon, Pirie, Gather 2009; 
Tomeš 2014), with growing demand for flexible transport which frequently leads to congestions, a sustainable upgrade of existing transport systems is inevitable.

Focusing on social role of transport systems, Hine (2009) states that transport should support social justice. Transport interconnects various places at local, regional or global levels which has many direct as well as indirect effects in the society. The very platitudinal mission of transport (i.e. transfer of persons or goods from $A$ to $B$ ) is still one of the elements of spatial interactions between various distant locations or communities. This mission of transport remains here in spite of growing importance of virtual mobility (Kenyon, Lyons, Rafferty 2002) which was previously expected to replace physical mobility by modern technologies (email, teleworking, internet social networks, on-line shopping, etc.). On the contrary, transport's social mission lies in its ability to facilitate accessibility of various activities (work, education, shopping, health-care, leisure time, etc.) for individuals, households or communities, which certainly predetermins life-quality, as argued by numerious studies (for example Cass, Shove, Urry 2005; Preston, Rajé 2007; Michniak 2008).

Banister, Berechman (2001) emphasize the complexity of the relationship and causality between transport infrastructure upgrading and economic growth, encouraging for recognising ,the multi-dimensional nature of the links between transport, location, development and the many other new factors relevant to our understanding of these processes... Merely improving accessibility, which translates into reduced travel time and higher travel volumes, would not be sufficient to generate growth" (Banister, Berechman 2001, p. 215).

\subsection{Transport infrastructure impacts: how to measure them?}

Neverheless, the search for impacts of transport infrastructure upgrading and motorway network enhancements particularly in studies published so far has been dominated by quantitative research. Most of these approaches have applied various economic variables and models to measure effects of transport network investments and their measurable effects in the respective territories. Not surprisingly, most of the studies have been rooted deeply in quantitative approaches, partly as a result of available data applied to estimate the impact of transport infrastructure upgrade (see e.g. Bruinsma, Rietveld 1998; Vickerman, Spiekermann, Wegener 1999; Holl 2004; Lakshmanan 2011; Crescensi, Rodrígues-Pose 2012 and many others). In Czech and Slovak geography environment, several approaches to research of effects of transport infrastructure improvements have been published, too (Viturka, Pařil, Tonev 2012; Ivanová, Masárova 2013; recently also Baláž, Dokupilová, Nežinský 2018), mostly using the qualitative research methods as a dominating approach. 
Quantitative analysis in transport geography plays is inevitable in describing urban trafic flows and travel behaviour, and statistical correlations provide us with empirical pictures that give weight to theoretical explanations. There is no doubt that a quantitative analysis is a very useful and necessary research tool but it cannot answer questions that demand an understanding of social processes nor provide a causal explanation. We agree with Røe (2000) that the problems associated with quantitative research can best be dealt with through interpretative, qualitative studies, which reveal everyday experiences and seek explanations that in turn may be supplemented with quantitative investigations.

As pointed out by Carr (2008), qualitative survey techniques like attitudinal surveys, focus groups, personal interviews, and participant-observation methods provide more detailed answers to current questions and issues regarding transportation and travel behavior. While qualitative methods offer great potential for transportation research, it cannot be argued that they should not be seen as a replacement to quantitative methods, but should be viewed as an extension to assist in explaining psychological and socially influential factors in travel behavior (see also Clifton, Handy 2003; Goulias 2003; Poulenez-Donovan, Ulberg 1994). When searching for data for such approach, apart from traditional methods focusing on activity-based modelling of travel behaviour (see for example Yamane, Fujiwara, Zhang 2005; Doherty et al. 2002 or Dowling, Colman 1995), modern studies increasingly use modern tools to detect human behaviour changes in space and time, for example internet-based and remote sensing technologies or GPS tracking (McNally, Rindt 2000).

As proposed by Chvátal (2018) and some other recent studies, a qualitative approach to estimate effects of new investments into transport infrastructure is necessary, too, since a combination of both (quantitative and qualitative approaches) may be a fruitful tool to cover the complexity of the issue.

\section{Evaluation methodology}

In this paper, our approach is broadening a view upon impacts of a R1 expressway section project in western Slovakia, stretching from Trnava to Banská Bystrica. The $\mathrm{R} 1$ expressway construction began back in the 1980s (individual sections). At the turn of the $20^{\text {th }}$ century there were several discontinuous sections in operation and the whole Trnava - Banská Bystrica section was put into operation in 2011. Our ambition was to assess the impacts by a systematic qualitative research leading to better understanding of complexity of social and economic development in regions affected by the expressway, focusing on aspects undetectable by quantitative methods.

Based on numerous studies (such as Rietveld 1994; MacKinnon, Pirie, Gather 2009, Chmelík, Marada 2014; Viturka, Pařil 2015 or Michniak 2015), the analysis 
of a large transport infrastructure project impacts should focus on three basic levels. First, intraurban dimension should be covered, detecting improvements of accessibility at local level. Second, intra-regional dimension should focus on effects within nodal regions. And third, attention should be paid to effects and improvements at inter-regional level. Many studies rooted in statistical methods sometimes show only limited impacts and very small accessibility changes. On the other hand, as Chvátal (2018) clearly indicates, any impacts of the infrastructure upgrading are more significantly detected in interviews with regional or local stakeholders, authorities, business companies or residents.

Our research was focused on impacts of new motorway network in territory adjacent to the R1 expressway. Based on a pilot evaluation of theoretical conditions in a sample area of Slovakia along the R1 expressway, we applied a method combining two following approaches: Investment Projects Holistic Assessment (IPHA) and Regional Socio-Economic Appraisal (RSEA). The combination of methods was designed to provide holistic approach where primary and secondary social, economic and environmental impacts (not detectable by a quantitative approach and interpretable by statistical methods) identified by RSEA are evaluated in IPHA and validated in qualitative interviews.

RSEA application included identification and mapping a wide spectrum of infrastructure impacts, out of which two following dimensions were applied in this paper:

- Primary socio-economic impacts caused by access to a new infrastructure network which are not detectable by a quantitative approach and interpretable by statistical methods.

- Secondary social, economic and environmental impacts that result from investments into transport infrastructure.

- IPHA utilises an expert panel approach. Fifteen experts were interviewed via telephone in the initial phase of the research, including representatives of selfgovernment authorities, business sector, non-governmental organisations and academic sphere. The experts involved in the process were identified in three ways: personal knowledge, literature review and other experts' recommendation. Later in the research, some of the experts were contacted again to upgrade the information or to verify some of the statements and data (a triangulation approach).

In the final phase, the specific deviations from the zero status before the intervention (new expressway section construction) identified using RSEA and evaluated through the expert panel were validated using in-depth interviews conducted with a selected sample of 5 experts, identified by a snowball approach with assistance of the panel experts from the initial research phase. The evaluation of answers was done using in depth, interpretive coding focusing attitudes and beliefs of 


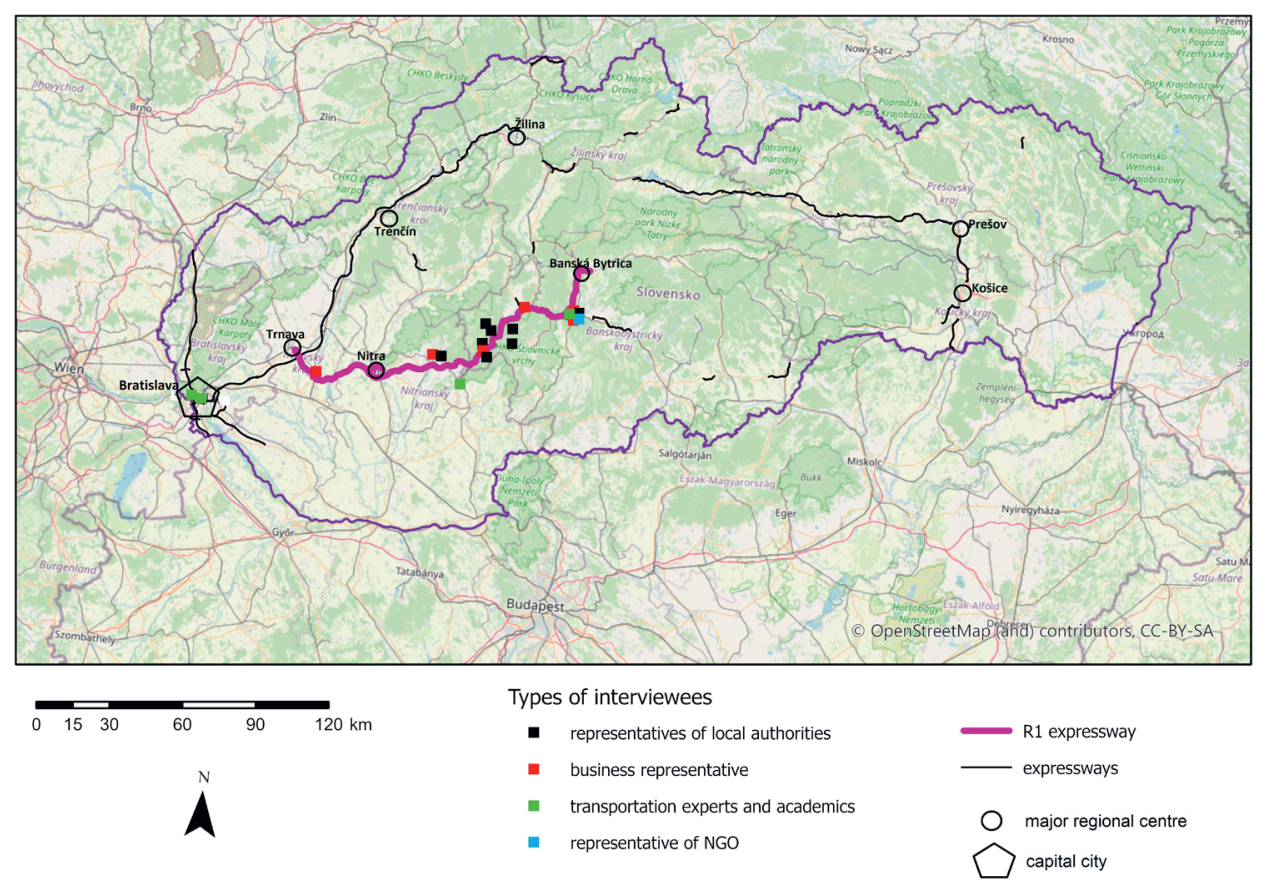

Fig. 1 - Location of the R1 expressway and interviewees included into the qualitative research

participants affiliated with the infrastructure project. Figure 1 shows locations/ affiliations of the institutions or companies represented by the interviewees included in the research. The academic experts were not necessarily located in the focus area, as their comprehension of the issue should be more general and unbiased no matter where their institutions have their seats.

\subsection{Interviews with representatives of local self-governmental authorities}

Mayors or vice-mayors of rural municipalities and towns/cities located alongside the new expressway were the primary interviewees ( 8 interviewees in total). In the interviews, the key question was whether (and to what extent) the new R1 expressway represented an incentive for local development. Further questions were focused on reasons (why or why not questions) and consequences perceived either by residents or community in general. The interviews were open-ended with no respective answers offered to the interviewees. The respondents in the panel of experts were selected to cover key stakeholders' groups (i.e., self-government authorities, business sector, non-governmental organisations, academic) and geographical area stretching along the $\mathrm{R} 1$ expressway (up to $20 \mathrm{~km}$ from the nearest 
exit). In the follow up in-depth interviews and selection of respondents we focused on the spatial differences in the evaluation of individual dimensions.

In these interviews, an emphasis was put on the fact that no positive nor negative impacts were adumbrated by the interviewers. We expected to receive unbiased subjective attitudes towards the expressway. Thus emphasizing positive or negative (or neutral) experience in the beginning of the interview was purely a respondent's free decision. Generally, subjectiveness of the interviewee's attitudes was supposed to be derived from the needs of the community and was not expected to include mayors' personal preferences. The main interview questions were as follows:

- What effects does the R1 expressway (Trnava-Banská Bystrica section) bring for your community?

- Do you see any particular relationship between the new expressway infrastructure and economic, social, demographic or any other aspects of your community's development? (Including sub-questions such as: What impacts on residents, local development, population dynamics, environment, etc. can you identify?)

\subsection{Interviews with business sector representatives}

Entrepreneurs and developers ( 7 in total, see Fig. 1) were selected to represent equally both manufacturing and services sectors, including all possible sizecategories. All interviewees were representatives of Slovak-based businesses (owners of Slovak companies). The key questions were the following:

- What effect does the new R1 expressway (Trnava - Banská Bystrica section) bring for economic development and business growth in your region?

- Do you see any particular relationship between the new expressway infrastructure and economic activities (enterprising) of your company?

- What do you consider crucial in transport networks development for your business?

- Is transport infrastructure quality important for location and development of your business activities?

\subsection{Interviews with transport experts (academic sector and non-governmental sector)}

Selection of interviewees covered various representatives involved into transport development and transport policy and planning documents at local or regional levels, including scientific investigators, transport planners and public administration professionals ( 5 in total). These were not necessarily rooted in the researched 
regions as some of them work for instance for national public academic institutions. Here, the aim was to gain a comprehensive picture of transport development trends. The main questions included the following: How does quality of transport accessibility affect socio-economic development of communities or regions? Can transport be considered as a decisive factor affecting development of a community or region? What transport mode is decisive for localisation of key economic investments? Can transport network be crucial for residential decision-making or can other aspects be more important?

\section{Key dimensions identified}

The evaluation of primary and secondary social, economic and environmental impacts identified by RSEA are evaluated in IPHA provided bases for identification of list of most important dimensions. These were subsequently validated in qualitative interviews and as the result we focused on the 11 dimensions where we identified key positive and/or negative effects. Although for the purpose of analyses we keep these 11 dimensions separately, in social and economic reality there are many overlaps among them and they influence each other.

For each dimension, scale of positive or negative externalities affected by the researched expressway section was identified (general outcomes presented in Table 1).

\subsection{Business environment enhancement}

As a consequence of improved transport opportunities, wider market environment and more customers are accessible which leads to better opportunities for manufacturing, distribution and consumption. New business opportunities are emerging which should be followed by growing investment volumes in the region. However, our survey indicates some obstacles for this dimension. Large companies will probably profit on it, on the other hand, small and medium enterprises might not. Cooperating sectors may witness profits, but some enterprises may fall into risk.

For companies like for instance Amazon whose logistics centre was recently open in the town of Sered', the motorway infrastructure had been crucial for their decision to operate their distribution plant with numerous labour opportunities here. According to Stone (2013) or LaVechia, Mirchell (2016), business activities of such companies cause mass and rapid closure of small businesses and thus generate higher unemployment rates consecutively. Better transport accessibility attracts large retail projects to the outskirts of cities such as Zvolen, where customers have comfortable conditions for shopping. This trend, on the other 
Table 1 - Frame evaluation of the identified dimensions

\begin{tabular}{|c|c|c|}
\hline Dimension & Evaluation & \\
\hline Business environment enhancement & Significantly positive effect & $\uparrow$ \\
\hline Growth of manufacturing & $\begin{array}{l}\text { Business inflow, enlargement of existing companies with } \\
\text { positive long-term expectations }\end{array}$ & $\uparrow$ \\
\hline Attractiveness for FDI & Positive effect perceived, basic precondition for some FDI's & $\uparrow$ \\
\hline $\begin{array}{l}\text { Lower costs and accessibility of goods } \\
\text { and services }\end{array}$ & $\begin{array}{l}\text { Concentration of retail and services may have positive } \\
\text { effects, compensated by outflow of smaller businesses }\end{array}$ & $\leftrightarrow$ \\
\hline Growing competitiveness & $\begin{array}{l}\text { Effects still expected, but already perceived in lack of labour } \\
\text { force and growing labour market competition }\end{array}$ & $\leftrightarrow$ \\
\hline Enhancement of labour opportunities & Significantly positive effect & $\uparrow$ \\
\hline Tourism development support & Significantly positive effect & $\uparrow$ \\
\hline $\begin{array}{l}\text { Social benefits of transport } \\
\text { infrastructure }\end{array}$ & Significantly positive effect & $\uparrow$ \\
\hline Mobility advantages & Significantly positive effect & $\uparrow$ \\
\hline Growing real estate value & $\begin{array}{l}\text { Significant effect which may disadvantage low-income } \\
\text { households }\end{array}$ & $\rightarrow$ \\
\hline Traffic accident rate & $\begin{array}{l}\text { Positive trend of accident rate decrease, compensated by } \\
\text { traffic intensity growth }\end{array}$ & $\rightarrow$ \\
\hline
\end{tabular}

Notes: $\uparrow$ significantly positive effects, $\rightarrow$ positive effects accompanied by negative impacts, $\leftrightarrow$ unevaluable

hand, brings small retail units in cities of the region to bankruptcy and generates busy traffic on peripheries of urban agglomerations.

Representatives of manufacturing sector are optimistic about long-term prospects of attractiveness for suppliers cooperating with large firms already operating in the area of western Slovakia, mainly car assemblies such as Jaguar-Land Rover in Nitra, PSA Peogeot-Citroën in Trnava or Kia Motors Slovakia in Žilina. All of these are highly reliant on just-in-time supply chains which makes them very sensible to effectiveness of transportation networks.

As an example, we can show the case of Žiar nad Hronom, a middle-sized town whose prospering economy is based on aluminium processing industry developed back in the communist era. Here, further prosperity prospects are clearly expected in relationship with the new R1 expressway. "The town of Žiar nad Hronom has a strong manufacturing potential and successful business environment closely related to the existing R1 expressway connection. This is a precondition for sustainable economic prosperity and growth of labour opportunities not only for the citizens of the town but for the region in general," says a representative of the local self-governmental office (interview on March $6^{\text {th }}, 2018$ ). 


\subsection{Manufacturing growth}

Activities related to manufacturing industry belong to decisive factors of regional development. Unlike farming sector, manufacturing is typically not sensitive to climatic or general natural conditions and relies strongly on transportation networks and accessibility, labour force and technical or technological infrastructure. This is one of the reasons why manufacturing is considered as one of the possible vectors and tools of regional development and it is used as one of the policies to mitigate the regional disparities in Slovakia (see Rusnák, Lehocký 2016).

Not surprisingly, our research revealed a strong positive effect of improved accessibility caused by the expressway perceived by local companies. Generally, if there is a good cooperation between a town and developers and available land, closeby areas become more attractive for investments, especially in locations near the expressway exits. For example, representatives of local authorities in Žarnovica, a small town in central Slovakia located on the R1 expressway, report on recent investments (Neuman or Tubex companies) and further ones still arriving here which is - among others - a consequence of better transport accessibility. Some other towns, such as Nová Baňa or Zvolen being well accessible via the expressway do not confirm the trend of new companies in their territories. It seems that the expressway is not the only aspect, there are many other factors such as global economic growth, etc. Following is the argumentation of business representative (interview on February $14^{\text {th }}, 2018$ ) in Zvolen, an industrial city in central Slovakia: "We have had this Continental company here for 10 years, and a lot of bare land closeby and we intended to develop an industrial park here but nothing is happening here. We can only hope that suppliers (of the automotive sector) will decide to shift themselves to the east from where Bratislava and Nitra are. But they are quiet, nobody is arriving here, they do not shift any further east of Nitra."

\subsection{Attractiveness for foreign direct investments (FDI)}

A good infrastructure brings higher attractiveness for global corporations as well as domestic capital and motivates them to invest. An improved connectivity lowers the costs and supports reliable and cost-effective supply-chain management. Poor transport services play negative role in competitiveness of regions or communities.

"Global production networks operate in just-in-time system and they are reliant on motorways that can meet their logistics requirements. Secondary, this brings profits for small businesses closeby such as insurance companies, cleaning services, construction firms who supply for those large global companies. So, they both are profiting, large manufacturing and logistics companies offer work 
opportunities and small local companies get more business chances there," states a transport geography expert (interview on February $12^{\text {th }}, 2018$ ).

Nitra-Sever Industrial Park is recently one of the most prosperous business areas in the country. British company Jaguar Land Rover who has opened a new car-assembly plant here relies on the R1 expressway axis between Trnava and Banská Bystrica. The company is to launch a full car production here with approximately 4,000 employees. Amazon is another company who developed their largest reverse logistics centre with over 60 thousand $\mathrm{m}^{2}$ in Sered', a town in southwestern Slovakia, directly connected to R1 expressway. Based on the interview of the company's local management, Amazon develops their distribution plants in locations with perfect transport network, available high-quality labour-force and legislation system allowing $24 / 7$ operation. The motorway thus ranks among the key preconditions for location of this type of investments.

However, some warn that although motorways are inevitable for large investments, it is not the only aspect. A motorway can bring transport costs saving but the higher the distance, the higher the transport costs. As one of the businessmen in our interview (on February $15^{\text {th }}$, 2018) notes: "Eastern Slovakian people believe that once the motorway is completed there, the investors will come soon. But because of poorer social capital and higher transport costs, the companies will hardly rush to be there."

Motorways can be a key argument for decision on large investments between individual target countries (or regions) with similar business environment. However, they may become neglected if the general business environment quality is poor. "Human capital qualification upgrading is another aspect that must be considered by an investing company... Lack of state incentives leads to incentives for regions, such as tax holidays, we need a model that would make some regions more attractive," says one of the interviewees active in business (interviewed on February $13^{\text {th }}, 2018$ ).

\subsection{Lower costs and accessibility of goods and services}

Efficient goods and services distribution and supply networks should lead to lower prices for customers. This results from the fact that transportation costs represent a significant part of the final costs (Krugman 1991, MacKinnon, Pirie, Gather 2009). As one of the interviewed business representatives (on February $14^{\text {th }}, 2018$ ) comments, "each business requires transport services, which must be efficient, fast and as cheap as possible, otherwise it negatively effects the final customer price."

This effect is still difficult to assess, on the other hand, as the case of companies such as Amazon shows, it is often associated with the concentration of trade and 
services in a few places and growing internet sales, which generates increase of traffic volumes and reduces jobs.

There is another adverse effect in business reallocation affiliated with mobility of customers. Specialised shopping malls and commercial and entertainment centres are built on cheap land outside of the settlements and attract customers on cost and quality of their services. These auto-dependent facilities usually spread out over large amounts of land. They create long distances between spaces where people actually live and where they go for shopping and/or entertainment. Although we may argue that there are certain benefits, such as creating local economic growth or employment for people, these are compensated by increased traffic pollution, loss of agricultural land and other environmental impacts.

\subsection{Growing competitiveness}

Growing competitiveness comes with expanding goods and services markets which is possible only in efficient transport networks (Ivanová, Masárová 2013). A wider offer of goods and services leads to lower costs and higher quality and these benefits are passed onto customers. Such environment supports innovations and technological progress. A developed regional transport infrastructure brings higher mobility opportunities and better distribution of goods within the region and is a basic condition for better inter-regional transportation (MacKinnon, Pirie, Gather 2009).

During our research, no direct significant effects of competitiveness were detected, except for the concentration of goods and services described above. Surprisingly, the highest competitiveness rate has been reported in relationship with regional labour market where business sector witnesses a lack of labour force. "Briefly, I cannot find enough skilled people to extent my business. Recently I still contract my former employees who commute from Bratislava. It is only a 40-minutes drive but they could have had higher salaries there working for a large foreign company there and my conditions are not competitive," reports one of the business sector respondents (interview on February $12^{\text {th }}, 2018$ ).

The whole situation has become even worse with large companies new to this region such as Amazon or Jaguar Land Rover companies. There is a fair concern that the fight for workers will become even tougher which might discourage some small or medium enterprisers in the area.

\subsection{Enhancement of labour opportunities}

The infrastructure opens more chances for working potential. New companies and economic sectors may subsequently come with new working positions. The 
potential of growing employment rate is a result of regional activities of large international corporations but also small domestic companies. For further business expansion, transport network accessibility brings the following benefits: transport costs decrease, accessibility improvement and enlargement of the market area. According to our research, establishment of some of the new companies in Žarnovica town came as a direct reaction to the expressway completion. One of the business representatives (interviewed on February $13^{\text {th }}, 2018$ ) says: "The expressway can bring benefits for regions with higher unemployment rate but also with available skilled labour fource. And so the problem of the poor regions will never be worked out without improvement of education and human capital development in general."

A perfect transport network can stimulate commute of labour force from distant places to existing companies here. The town of Žiar nad Hronom and its economic power is a good example. As indicated by our respondents, the transport infrastructure is a significant incentive for the local aluminium concern that has developed about 180 various production plants here.

\subsection{Tourism development support}

Tourism industry plays an important role due to its high potential to become one of the economic growth sources. In Slovak economy, tourism generates about 3\% of the national GDP, stimulates employment growth with relatively low input costs, supports enterprising, boosts demand, has social and environmental impacts, brings seasonal employment in some regions and helps mitigate regional differences. For regions with weakening position of manufacturing as the former leading sector and growing role of tourism, transport networks are crucial (see Michniak et al. 2015).

Growing tourism has been reported also in the research area by numerous authorities, entrepreneurs, or other stakeholders. "Before, we had not seen such high interests of incoming tourists. To purchase a weekend house here has become difficult. ... We run here a ski-lift, one of the closest to Bratislava. Our ski-resort, a small one though, but now well accessible, has to meet much higher demand for ski-trips," report two representatives of local authorities in the region (on February $26^{\text {th }}, 2018$ ).

The research area includes a part of what in Slovakia's geography is known as "dispersed settlement" territory being highly attractive for second housing. The scattered form of settlement in the countryside offers an intimacy compared to crowded tourist resorts and offers valuable natural landscape with both winter and summer leisure-time activities (ski-lifts, water, hiking and biking trails). The interviews clearly show that better transport accessibility stimulates demand for 
real estates for tourism purposes, mainly among residents of the capital city of Bratislava. On the one hand, this caused growth of the prices of real estates. Shortterm tourism has been thriving here together with prospering local economics. Numbers of visitors of existing tourism resorts and facilities have been rising in the region. A municipality of Hodruša-Hámre (in Žarnovica district) is a typical example of this trend (revitalisation of so-called tajchs - old technical water reservoirs, development of biking trail networks, mountain hiking). Transport infrastructure supports the tourism potential accompanied by growing purchase power on the one hand, and lower traffic rate of local roads on the other. "Transport matters in my leisure time too. My family and I do biking and now it is perfect even on roads where we could not ride before, the regional and local roads where it was not possible due to the heavy trucks." (An interview with a businessman, February $27^{\text {th }}, 2018$ )

\subsection{Social benefits of transport infrastructure}

Road infrastructure surely changes the landscape. An improved connectivity brings regions closer to the rest of the world and brings new stimuli and impacts, too. In this context, social and cultural impacts are important. Our respondents perceive growing urban-rural interconnection as a positive fact that enables to reduce social differences and stimulates formation and expansion of social networks. These phenomena are hardly detectable by economic indicators, but they are valuable in social development.

In the second half of the $20^{\text {th }}$ century, economic impacts together with labourmarket impacts were related with growing urbanisation rates and migration of young generation to urban environment following their work. In Slovakia, typical rural houses became surprisingly generous and big but empty and inhabited only by the parental couple or one of the parents. Geographers (Ira 2003; Káčerová, Mládek 2012; Bucher 2012) point to rural depopulation and population ageing. Time-demanding jobs and stress can significantly hamper the development of family-related social networks of family members living apart.

The comments of the respondents agreed on a positive change. "I have lived and worked in Bratislava for 12 years already. I can say that after they completed the expressway, I see my parents and my brother more frequently. I visit my parents in Zvolen more often now, it is easy to jump in my car and ride up there and back in just one day, if there is not enough time for a longer visit. But, more importantly, who now dares to drive is my dad who is quite old now, and he can drive to my place near Bratislava, it is easier along the expressway. Without the expressway, he wouldn't have dared to," argues on of the requested businessmen (interviewed on February $\left.14^{\text {th }}, 2018\right)$. "Everyone's fighting against the time now. The time is 
precious related to transport, everyone wants to use cheap and efficient transport. And if I save time doing my duties, I can have more time for myself, my family and there is less stress there," says another business representative (interviewed on February $\left.15^{\text {th }}, 2018\right)$.

\subsection{Mobility advantages}

Despite the companies profitting on improving accessibility, some enjoy it more than the others. The higher the income, the more willing to utilise the transport infrastructure and economic opportunities. An inclusive growth supported by a proper accessibility of rural, underdeveloped and poor regions may bring advantages to all segments of the society.

According to our research, mobility advantages are strongly perceived by all stakeholders, especially business representatives who emphasize the economic benefits of improved accessibility, along with better travel comfort and safety. "Within the last 20 years, especially in the late 1990s we used to travel to Bratislava and Vienna intensively, the journeys were always frustrating, time-consuming. We used to make it three or four times a week to Bratislava and this R1 expressway per partes brought considerable improvement of comfort for our business activities and plans," reports one of the business representatives (interviewed on April $4^{\text {th }}$, 2018).

Some analyses point to doubtfulness of the benefits generated by new motorway networks since there appear multiple factors affecting the business environment (as described for instance by Bruinsma, Rienstra, Rietveld 1997; Banister, Berechman 2001 or Chvátal 2018). "Some claimed that the motorway construction was not cost-effective because the traffic intensity was not high enough. However, the traffic intensity has been growing recently. We can assume that there are more travellers as it is easier to do the business now," comments a transportation expert (interviewed on March $5^{\text {th }}$, 2018).

The barriers between motorways and target points (mainly in large cities such as Bratislava or Banská Bystrica) are perceived negatively. Lack of transport integration in large cities generates traffic congestions and delays. The interviewees propone better integration of passenger transport systems which would enable better permeability of road transport networks in urban environment. "Carrying new windows to my customer in Bratislava, it takes me 30 minutes to reach Bratislava but then an hour to reach the city centre. The fringe belt surrounding Bratislava is impermeable, but you cannot bypass it," states a business representative (interviewed on April 10 $0^{\text {th }}, 2018$ ).

Apart from the accessibility improvements, all transport solutions diverting transit traffic out from the urbanised areas are welcome by both local authorities 
and business representatives. On the other hand, missing bypass roads are perceived negatively. "The city of Zvolen is just a bottle-neck, it is always stuck with heavy traffic by locals and by those travelling to Košice, too. We need the northern city bypass because the main road crosses the inner city," reports a local authority representative (interviewed on February $12^{\text {th }}, 2018$ ). "The road towards Lučenec is just a hell for us, it becomes a hell on earth for everyone driving through here between 7 and 8 a.m. Banská Bystrica and Brezno have their bypass roads and so they are peaceful," claims a business representative (interviewed on March $6^{\text {th }}, 2018$ ).

Many times, the interviewees commented on missing efficient road connection to other towns such as Krupina, Detva, Rimavská Sobota or Ružomberok. According to a business representative (interviewed on February $14^{\text {th }}, 2018$ ), “...There is the PPS company near Detva fighting for survival, they use mass transport and would profit on the expressway."

\subsection{Growing value of real estate}

The real estate properties values generally tend to grow with transport infrastructure upgrading (see e.g. Cohen, Paul 2007). To avoid any sophisticated statistical assessment of property values of various types in various locations, we rather focused on experiences reported by local representatives. Broadly speaking, all interviewees claimed growing interest of real estate agencies and developers in construction of new homes and apartments in our research area. This trend is surely supported by a general economic boom in the country. However, locations which people or companies choose for property investments are very often those with good transport accessibility.

"We can observe a growing interest in building land. A few years ago we thought we would never be too attractive as our town is far from the city of Zvolen. But now everybody has a car and the perception of what is near and what is far has changed," says a local municipality representative (on April 11 ${ }^{\text {th }}, 2018$ ).

As one of the interviewees says, the towns located close to the expressway can profit "...because they are well accessible. According to numerous studies the distance $20 \mathrm{~km}$ from the nearest motorway counts the same as a location directly on the motorway. This is proved by examples of successful towns such as Galanta ( $4 \mathrm{~km}$ from the R1 expressway), Levice $(20 \mathrm{~km})$ or Vráble $(15 \mathrm{~km})$ where many automotive sector subcontractors have launched their productions. On the other hand, town of Krupina $27 \mathrm{~km}$ far from the expressway suffers from the lack of new business investments" (from an interview with a transportation sector expert, April 11 ${ }^{\text {th }}$, 2018).

What brings profit for some stakeholders may bring social costs for the state. Towns, cities and urban environment generally have become too expensive and 
residents seek for cheaper living solutions. As a result, we see increasing traffic loads, pollutions and noise (cf Cohen, Paul 2007; Hine 2009 or Lakshmanan 2011).

\subsection{Traffic accident rate}

General national statistics on the traffic accidents in the country show a positive trend of falling numbers of casualties or injuries reported in traffic accidents (MV SR 2020). Nevertheless, these positive trends result from multiple factors including vehicle stock modernisation (more safe cars than back in the 1990s) and changing methodology of accident registration process. On the other hand, these trends are highly positive considering the growing general mobility, increasing motorisation rate and growing traffic intensities.

A sober and correct examination of traffic accident rate change along the R1 expressway route before and after its construction does not exist. Meanwhile, methodology of road accident rate monitoring carried out by state authorities has changed, too. Anyway, comparing the data presented by the Slovak Road Administration office (www.ssc.sk) reveals considerable decrease of road accident rates after opening each particular R1 expressway section and numerous traffic accidents are reported only at regional and local road network segmetns.

All respondents reported on a significant traffic safety growth. They frequently commented on an indirect positive impact on safety of pedestrians and cyclists within communities. One of the local authority representatives says (on April $\left.10^{\text {th }}, 2018\right)$ that “...There were thousands of cars transitting through the town centre before, we could not allow our kids to walk in the street. Now it is so much different."

Business sector representatives frequently commuting to the capital city expressed highly positive reactions. Along with the improved accessibility, road traffic safety was one of the most praised benefits of the new expressway.

"My father used to run a business. The journey from Zvolen to Bratislava was just an adventure. We used to make it nearly everyday, sometimes even three times a day as he had to visit a lot of companies. Sometimes it was nearly a death ride. We had been waiting for a long time... but now I only turn my cruise control on and enjoy driving back from Bratislava," reports a business representative (interviewed on February $14^{\text {th }}, 2018$ ).

Another enterpriser (interviewed on April 11 ${ }^{\text {th }}, 2018$ ) says "I usually make the journey twice a week. People say that you can easily fall asleep driving on the new expressway, but it is certainly safer than before. It is a redemption for us, including the services offered along the expressway." 


\section{Conclusions}

As we demonstrate in our analytical approach, impact of the road infrastructure development is a complex issue and requires combination of quantitative and qualitative approaches. The investments into the roads are to some extend justifiable in Slovakia by the underdeveloped networks, on the other hand climate change and emerging policy framework of the European Union push for more advanced approaches and focus on smart and sustainable mobility.

The results of the research indicate predominantly positive perception by the infrastructure users and key stakeholders. Although there are many structural barriers important for the further development of the region, the road infrastructure is perceived as a basic point from which further solutions can then be derived.

The analysis positively verified the initial research hypotheses, which assumed that the impact of the highway on the region/locality is significantly broader and therefore difficult to analyse only using quantitative indicators - such as the number and structure of enterprises located in the monitored territory, local government revenues or labour market trends. The identified indirect social, environmental and economic impacts resulting from the investments are mostly positive. The exception is the problem of emissions from traffic, traffic congestions and noise, which may decrease locally, but increased in volume.

The research results especially indicate that there is a strong factor in the impact of transport infrastructure on the social and economic development of the so-called "endpoints". In this case the catchment area of Bratislava/West and the Zvolen - Banská Bystrica conurbation. Nevertheless, local municipalities between the endpoints have also a positive perception of the infrastructure impacts (i.e., mayors of municipalities). On a purposefully open and neutral introductory question on social and economic impacts during the interviews the addressed representatives assessed the impacts as positive and started by naming the positive impacts on their municipality/town. The exemptions are identified among small and medium enterprises, who perceive an increased competition for human resources enabled by better accessibility (especially commuting to the endpoints).

The identified negative externalities include an increase in transport, an increased traffic loads and noise in the municipalities through which the expressway passes and the unresolved property and legal relations. In the evaluation, these were perceived by the local governments as partially solvable problems (construction of anti-noise measures) or a temporary agenda (resolution of property and legal relations). A specific question is how the expected decline in employment in the trade and services sector can be offset by the creation of new jobs in industry and other types of services (for example, related to the development of tourism) and how commuting may lead to resettlements, urbanisation and gradual transformation of some rural municipalities into recreational and weekend spaces. 
The results of the qualitative evaluation indicate importance of newly built infrastructure for creating systemic preconditions for further development of the territory. Mitigating negative externalities affiliated with the investment would require addressing structural barriers important for the further development of the region, making it attractive for the inhabitants and investments.

\section{References}

ADLER, H.A. (1987): Economic appraisal of transportation projects: A manual with case studies. Johns Hopkins University Press, Baltimore.

BALÁŽ, V., DOKUPILOVÁ, D., NEŽINSKÝ, E. (2018): Do motorways induce wider economic benefits? Evidence from the Slovak Republic. Ekonomický časopis, 66, 5, 431-464.

BANISTER, D., BERECHMAN, Y. (2001): Transport investment and the promotion of economic growth. Journal of Transport Geography, 9, 3, 209-218.

BOROWSKA-STEFAŃSKA, M., KOWALSKI, M., WIŚNIEWSKI, S. (2020): Changes in travel time and the load of road network, depending on the diversification of working hours: case study the Łodź Voivodeship, Poland. Geografie, 125, 2, 211-241.

BRUINSMA, F.R., RIENSTRA, S.A., RIETVELD, P. (1997): Economic Impacts of the Construction of a Transport Corridor: A Multi-level and Multi-approach Case Study for the Construction of the A1 Highway in the Netherlands. Regional Studies, 31, 4, 391-402.

BRUINSMA, F., RIETVELD, P. (1998): The accessibility of European cities: theoretical framework and comparison of approaches. Environment and Planning A, 30, 3, 499-521.

BUCHER, S. (2012): Aspects of the phenomenon of demographic population ageing in Czechia and Slovakia: time and regional dimensions. Human Geographies - Journal of Studies \& Research in Human Geography, 6, 1, 25-33.

BUTTON, K. (1995): What Can Meta-analysis Tell Us about the Implications of Transport? Regional Studies, 29, 6, 507-517.

CASS, N., SHOVE, E., URRY, J. (2005): Social exclusion, mobility and access. The Sociological Review, 53, 3, 539-555.

CARR, K. (2008): Qualitative research to assess interest in public transportation for work commute. Journal of Public Transportation, 11, 1, 1-16.

CHMELÍK, J., MARADA, M. (2014): Assessment of the Impact of a New Motorway Connection on the Spatial Distribution and Intensity of Traffic Flows: a Case Study of the D47 Motorway, Czech Republic. Moravian Geographical Reports, 22, 4, 14-24.

CHVÁTAL, F. (2018): Vliv dopravní dostupnosti území na ekonomický a regionální rozvoj v České republice. Doctoral dissertation, Masaryk University, Faculty of Science, Brno.

CLIFTON, K.J., HANDY, S.L. (2003): Qualitative methods in travel behaviour research. Transport survey quality and innovation. Emerald Group Publishing Limited, 283-302.

COHEN, J.P., PAUL, C.M. (2007): The impacts of transportation infrastructure on property values: A higher-order spatial econometrics approach. Journal of Regional Science, 47, 3, 457-478.

CRESCENZI, R., RODRÍGUEZ-POSE, A. (2012): Infrastructure and regional growth in the European Union. Papers in regional science, 91, 3, 487-513.

DOHERTY, S.T., MILLER, E.J., AXHAUSEN, K.W., GÄRLING, T. (2002): A conceptual model of the weekly household activity-travel scheduling process. Travel behaviour: Patterns, implications and modelling, 233-264. 
DOWLING, R.G., COLMAN, S.B. (1995): Effects of increased highway capacity: results of household travel behavior survey. Transportation Research Record, 1493, 143-149.

GOULIAS, K.G. (2003): On the role of qualitative methods in travel surveys. Transport survey quality and innovation, 319-330.

GRZESZCZAK, J. (1972): Polarization theory: Some basic notions and concepts. Geographia Polonica, 21, 27-40.

GUANGQING, CH. (2014): Economic Development. In: Garret, M. (ed.): Encyclopedia of Transportation. Social Science and Policy. SAGE Publications, Thousand Oaks, Los Angeles, 2, 453-456.

HABRMAN, M., ŽÚDEL, B. (2017): Od Tatier k Dunaju, dial'nice stavajú: Vplyv dialnic a rýchlostných ciest na regionálnu mieru nezamestnanosti. Komentár 2017, 10, Inštitút finančnej politiky, MF SR.

HAMADA, R., KASAGRANDA, A. (2012): Dial'nica D1 a jej vplyv na mieru nezamestnanosti v Trenčianskom kraji. Geographia Cassoviensis, 6, 2, 28-36.

HENSHER, D.A., TRUONG, T.P., MULLEY, C., ELLISON, R. (2012): Assessing the wider economy impacts of transport infrastructure investment with an illustrative application to the North-West Rail Link project in Sydney, Australia. Journal of Transport Geography, 24, 292-305.

HINE, J. (2009): Transport and Social Justice. In: Knowles, R., Shaw, J., Docherty, I. (eds.): Transport Geographies: Mobilities, Flows and Spaces, Blackwell Publishing, Oxford, 49-61.

HOLL, A. (2004): Manufacturing location and impacts of road transport infrastructure: empirical evidence from Spain. Regional Science and Urban Economics, 34, 3, 341-363.

HOYLE, B., SMITH, J. (1998): Transport and development: conceptual frameworks. In: Hoyle, B., Knowles, R. (eds.): Modern transport geography. John Wiley \& Sons, Chichester, 13-40.

HUDEČEK, T., CHURAŇ, R., KUFNER, J. (2011): Accessibility of Prague by Roadway Transport from 1920 to 2020. Geografie, 116, 3, 317-334.

IRA, V. (2003): Rural space in Slovakia: Changes of spatial structures and spatial behavioural patterns. AUC-Geographica, 38, 1, 119-130.

IVANOVÁ, E., MASÁROVÁ, J. (2013): Importance of road infrastructure in the economic development and competitiveness. Economics and Management, 18, 2, 263-274.

KÁČEROVÁ, M., MLÁDEK, J. (2012): Population ageing as generation substitutions: Economic and social aspects. Ekonomický časopis, 3, 60, 259-276.

KENYON, S., LYONS, G., RAFFERTY, J. (2002): Transport and social exclusion: investigating the possibility of promoting inclusion through virtual mobility. Journal of Transport Geography, 10, 3, 207-219.

KOMORNICKI, T., ROSIK, P., ŚLESZYŃSKI, P., SOLON, J.,WIŚNIEWSKI, R., STĘPNIAK, M., GOLISZEK, S. (2013): Impact of the Construction of Motorways and Expressways on Socio-Economic and Territorial Development of Poland. Ministry of Regional Development, Warsaw.

KOREC, P. (1983): Postavenie magistrál a polymagistrál v dopravnej sieti územia. Acta Facultatis Rerum Naturalium Universitatis Comenianae, Geographica, 22, 57-67.

KOREC, P., ONDOŠ, S., MATU, P., PÁLKOVÁ, P. (2005): Regionálny rozvoj Slovenska v rokoch 1989-2004: Identifikácia menej rozvinutých regiónov Slovenska. Geo-grafika, Bratislava.

KRUGMAN, P. (1991): Increasing returns and economic geography. Journal of Political Economy, 99, 3, 483-499.

KVIZDA, M. (2017): Regional terminals on high-speed lines: to build or not to build? A report from the $11^{\text {th }}$ Telč seminar 2016. Review of Economic Perspectives, 17, 3, 331-334. 
LAKSHMANAN, T.R. (2011): The broader economic consequences of transport infrastructure investments. Journal of Transport Geography, 19, 1, 1-12.

LAVECCHIA, O., MITCHELL, S. (2016): Amazon's Stranglehold: How the Company's Tightening Grip Is Stifling Competition, Eroding Jobs, and Threatening Communities. Washington: Institute for Local Self-reliance. https://ilsr.org/wp-content/uploads/2016/11/ ILSR_AmazonReport_final.pdf (11.11.2019).

MACKINNON, D., PIRIE, G., GATHER, M. (2009): Transport and economic development. In: Knowles, R., Shaw, J., Docherty, I. (eds.): Transport Geographies: Mobilities, Flows and Spaces. Blackwell Publishing, Oxford, 10-28.

MARADA, M., KVĚTOŇ, V., VONDRÁČKOVÁ, P. (2006): Železniční doprava jako faktor regionálního rozvoje. Národohospodářský obzor, 4, 4, 51-59.

MARADA M., KVĚTOŇ V., VONDRÁČKOVÁ P. (2010): Doprava a geografická organizace společnosti v Česku. Edice Geographica, 2, ČGS, Praha.

MCNALLY, M.G., RINDT, C.R. (2000): The activity-based approach. In: Hensher, D.A., Button, K.J. (eds.): Handbook of transport modelling. Pergamon, Amsterdam, 35-52.

MIČÚCH, M., TVRZ, S. (2015): Aby nezamestnanost' v okrese klesla, iba otvorit dial'nicu nestačí, Biatec, 23, 8, 4-10.

MICHNIAK, D. (2008): Rovnováha práce a bývania v jednotlivých okresoch na Slovensku v kontexte kvality života. Geographia Slovaca, 25, 47-61.

MICHNIAK, D. (2015): Main problems of transport infrastructure development in Slovakia and effects on regional development. Geographia Polonica, 88, 1, 21-39.

MICHNIAK, D., WIĘCKOWSKI, M., STĘPNIAK, M., ROSIK, P. (2015): The impact of selected planned motorways and expressways on the potential accessibility of the Polish-Slovak borderland with respect to tourism development. Moravian Geographical Reports, 23, 1, 13-20.

MIKLOŠ, M. (2016): Rýchlostná cesta R1 regiónu ekonomicky velmi nepomohla.INESS, Inštitút ekonomických a spoločenských analýz, https://iness.sk/sk/stranka/11882-Rychlostna-cesta-R1-regionu-ekonomicky-velmi-nepomohla, Bratislava (9.12.2018).

MIKLOŠ. M, HABRMAN, M. (2018): Pohronská paráda: Prípadová štúdia rýchlostnej cesty R1. Komentár 2018, 5, Inštitút finančnej politiky, MF SR.

MDVRR SR (2015): Operačný program Doprava 2007-2013 (Verzia 6.0). Ministerstvo dopravy, výstavby a regionálneho rozvoja Slovenskej republiky, Bratislava, https://www.mindop.sk/ index/open_file.php?file=doprava/dopinfra/program/Dokumenty/OPD6/OP_Doprava_verzia_6_0.pdf (11.11.2019).

MV SR (2020): Prehlad základných štatistických ukazovatel'ov dopravnej nehodovosti za roky 1966 až 2019. Ministerstvo vnútra Slovenskej republiky, https://www.minv.sk/?statisticke-ukazovatele-sluzby-dopravnej-policie (21.7.2020).

OYESIKU, K. (2004): Policy Directions in Urban Transportation in Perspectives on Urban Transportation in Nigeria. In: editor: název knihy, NITT Publications, 171-202.

PERROUX, F. (1950): Economic space: theory and applications. The Quarterly Journal of Economics, 64, 1, 89-104.

POULENEZ-DONOVAN, C. J., ULBERG, C. (1994): Seeing the Trees and Missing the Forest: Qualitative Versus Quantitative Research Findings in a Model Transportation Demand Management Program Evaluation. Transportation Research Record: Journal of the Transportation Research Board, 1459, 1-6.

PRESTON, J., RAJÉ, F. (2007): Accessibility, mobility and transportrelated social exclusion. Journal of Transport Geography, 15, 3, 151-160.

PŠENKA, T. (2008): Dial'nice a regionálny rozvoj. Geografia Cassoviensis 2, 1, 128-131. 
RIETVELD, P. (1994): Spatial economic impacts of transport infrastructure supply, Transportation Research Part A: Policy and Practice, 28, 4, 329-341.

RODRIGUE, J.-P., COMTOIS, C., SLACK, B. (2009): The Geography of Transport Systems. Routledge, London, New York.

RøE, P.G. (2000): Qualitative research on intra-urban travel: an alternative approach. Journal of Transport Geography 8, 2, 99-106.

RUSNÁK, J., LEHOCKÝ, F. (2016): Priestorová distribúcia a sektorová štruktúra priemyslu na Slovensku. Acta Geographica Universitatis Comenianae, 60, 1, 69-102.

SSC (2018): Prehl'ad údajov o sieti cestných komunikácií SR. Územné členenie: SR - kraje, Slovenská správa ciest, Bratislava, https://www.cdb.sk/files/documents/cestna-databanka/ vystupy-cdb/2018/kniha_ck_kraj-okres_2018-01-01.pdf (10.11.2019).

STONE, B. (2013): The Everything Store: Jeff Bezos and the Age of Amazon. Little, Brown \& Co, New York.

TOMEŠ, Z. (2014): Konkurence a výkonnost na evropských železnicích. Masarykova univerzita, Brno.

VICKERMAN, R., SPIEKERMANN, K., WEGENER, M. (1999): Accessibility and economic development in Europe. Regional studies, 33, 1, 1-15.

VICKERMAN, R. (2000): Evaluation methodologies for transport projects in the United Kingdom. Transport Policy, 7, 7-16.

VITURKA, M., PAŘIL, V. (2015): Regional assessment of the effectiveness of road infrastructure projects. International Journal of Transport Economics, 42, 4, 507-528.

VITURKA, M., PAŘIL, P., TONEV, P. (2012): Hodnocení účelnosti projektů výstavby dopravní infrastruktury. Případová studie dálnic a rychlostních silnic České republiky. Urbanismus a územní rozvoj, 15, 2, 28-34.

YAMANE, K., FUJIWARA, A., ZHANG, J. (2005): Analysis of travel behavior array pattern from the perspective of transportation policies. Journal of the Eastern Asia Society for Transportation Studies, 6, 91-106.

\section{ACKNOWLEDGEMENTS}

This paper was supported by the APVV project No. APVV-17-0141 titled "Analysis of Barriers in Access to Employment for Marginalized Groups of Population: Selected regions of Slovakia in socio-economic, geographic and socio-anthropological perspective".

\section{ORCID}

RICHARD FILČÁK

https://orcid.org/0000-0001-6925-5181

ALENA ROCHOVSKÁ

https://orcid.org/0000-0001-6126-7700

MARCEL HORŇÁK

https://orcid.org/0000-0003-0071-4997 